\title{
Morphometric Characteristics and Length-Weight Relationship of Russian Sturgeon Juveniles Fed with Different Ratio
}

\author{
Raluca-Cristina ANDREI (GURIENCU) ${ }^{1 *}$, Victor CRISTEA ${ }^{1}$, Lorena DEDIU ${ }^{1}$, Mirela CREȚU ${ }^{1}$, Angelica \\ Ionelia DOCAN ${ }^{1}$
}

${ }^{1}$ Faculty of Food Science and Engineering, Dunărea de Jos University of Galaţi, Domnească Street no.47, 800008, Galaţi, Romania

${ }^{*}$ Corresponding author, e-mail: raluca.andrei@ugal.ro

Bulletin UASVM Animal Science and Biotechnologies 74(2)/ 2017

Print ISSN 1843-5262; Electronic ISSN 1843-536X

DOI:10.15835/buasvmcn-asb: 0010

\begin{abstract}
The aim of this paper was to analyze some morphometric characteristics and the correlation between them for Russian sturgeon juveniles (Acipenser gueldenstaedtii) reared in a recirculating aquaculture system fed at different fed with different ratio: $1 \%$ body weight (BW), 1.5\% BW, 2\% BW and ad libitum feeding (which was around 2.8\% BW).Fish, with an average body mass around $248.194 \pm 1.59 \mathrm{~g}$. Following biometric measurements were made for each fish, including weight (W), total length (TL), standard length (SL), fork length (FL), maximum body depth (last depth of caudal peduncle, H); preanal distance (AD), predorsal distance (PD), length of head (C), preorbital distance (PO), length of pectoral fin (LPF), interorbital distance (ID), maximum width of head (MH), width of mouth (WM), width of the head at the level of the mouth (WHM). The obtained results showed significant differences between all morphometric measurements $(p<0.05)$ for all the experimental variants, emphasizing that in the ad libitum feeding all morphometric measurements were significantly higher than in the other experimental variants. In order to highlight more eloquent these differences, were developed some linear regressions between the morphometric measurements and significant positive correlation $(\mathrm{p}<0.05)$ between dependent and independent variables were found.
\end{abstract}

Keywords: Russian sturgeon, morphological characters, growth, recirculating aquaculture system

\section{INTRODUCTION}

Five species of sturgeon once migrated from the Black Sea into the Danube for spawning: the anadromous species, Beluga (Huso huso), Russian sturgeon (Acipenser gueldenstaedtii), Stellate sturgeon (Acipenser stellatus), Sterlet (Acipenser ruthenus), Ship sturgeon (Acipenser nudiventris) (Bacalbașa-Dobrovici et al., 1997). Nowadays, only four sturgeon species survived: beluga (Huso huso), Russian sturgeon (Acipenser gueldenstedii), Stellate sturgeon (Acipenser stellatus) and Sterlet (Acipenser ruthenus), but they are in a major decline (Birstein et al., 1997; Barannikova et al., 2000). This decline is predicted to continue as illegal fishing at sea, and in rivers, for caviar will soon result in the extinction of the remaining natural wild population. In the immediate future, survival can only depend on stocking (http:// www.iucnredlist.org).

The Danube river system has long been subjected to anthropogenic influence from a number of sources altering the entire ecosystem. The fish community, in particular sturgeon species, has been greatly impacted by these changes (Rosten et al., 2012). Loss of habitat has occurred throughout the system and in particular, historical spawning grounds are no longer accessible due to the construction of the hydropower dams Iron 
Tab. 1. Proximate composition (\%) of the feed

\begin{tabular}{cc}
\hline Parameters & Quantity \\
\hline Crude protein (\%) & 42 \\
\hline Crude fat (\%) & 18 \\
\hline Crude cellulose (\%) & 1.2 \\
\hline Ash (\%) & 6.1 \\
\hline Phosphorus (\%) & 0.9 \\
\hline Vitamin A (IU) & 10.000 \\
\hline Vitamin C (mg Kg & 150 \\
\hline Vitamin E (mg Kg & 200 \\
\hline Vitamin D3 (IU) & 2430 \\
\hline $\begin{array}{l}\text { Ingredients: fish meal, soybean extracts, maize gluten, rape oil, hemoglobin, wheat gluten, blood } \\
\text { meal. }\end{array}$
\end{tabular}

Gate I \& II at river kilometers 942 and 863 in 1970 and 1984 respectively (Hensel et al., 1997). These barriers divide the lower and the mid Danube halving the historic spawning migrations of sturgeons which were documented extending as far upstream as Vienna (Bacalbaşa-Dobrovici et al., 1997).

The decline in natural populations has increased interest in aquaculture caviar production, and the number of aquaculture farms is rapidly increasing (Yarmohammadi et al., 2011). During the 20th century, world demand for sturgeon meat and caviar has inflated the economic value of sturgeon fishing, with the value of beluga caviar estimated at the US \$ 1000 per 100 grams (Suciu et al., 2008). This, together with the development of intense fishing pressure following a lack of fishing controls after the Romanian revolution in 1989 (Kynard et al., 2002) has caused, despite listing in year 2009 of all remaining Lower Danube river species, in Annex II of the Convention on International Trade in Species of Endangered Fauna and Flora (CITES), the sharp decline in recent documented catches of sturgeon. That is why is essential to increase the sturgeon production in aquaculture, in order to diminish the pressure on the wild stocks and to help the restoring of the wild population and to ensure their survival.

Fish are very sensitive to environmental changes and quickly adapt themselves by changing necessary morphometrics (Hossain et al., 2010).

The morphometric relationships between various body parts of fish can be used to assess the welfare of individuals and to determine the possible difference between the individuals from the same species (King, 2007). Morphometric measurements and statistical relationships of fishes are imperative for both fishery biology (Mustafa et al., 2008) and taxonomy studies.

The aim of this research was to analyze some morphometric characteristics and the correlation between them for Russian sturgeon juveniles (Acipenser gueldenstaedtii) reared in a recirculating aquaculture system fed at different ratio: $1 \%$ body weight $\mathrm{BW}$ day $^{-1}, 1.5 \% \mathrm{BW}_{\text {day }}{ }^{-1}$, $2 \% \mathrm{BW}$ day $^{-1}$ and ad libitum feeding.

\section{MATERIALS AND METHODS}

The study was conducted in Galați, at the Romanian Center for the Modeling of Recirculating Aquaculture Systems (MoRAS), facility of University Dunărea de Jos, Romania, during 6 weeks. 144 juvenile Russian sturgeons (Acipenser gueldenstaedtii), with an average body mass around $248.194 \pm 1.59 \mathrm{~g}$, were divided into eight rearing units, each having a volume of $0.700 \mathrm{~m}^{3}$ (18 juvenile Russian sturgeons per rearing unit).

The experiment was carried out in duplicate. Fish were fed manually, with extruded pellets for sturgeons with the diameter of $3 \mathrm{~mm}$ (Table 1), three times per day at different feeding ratio: 1\% BW day ${ }^{-1}, 1.5 \% \mathrm{BW}_{\text {day }}{ }^{-1}, 2 \% \mathrm{BW}_{\text {day }}{ }^{-1}$ and ad libitum (which was calculated at the end of the experimental period, around $2.8 \% \mathrm{BW}$ ). The ad libitum feeding was done until the fish have not shown interest in administered fed (over an hour).

Fish were reared under natural photoperiod and no mortality occurred during the entire experimental period. 


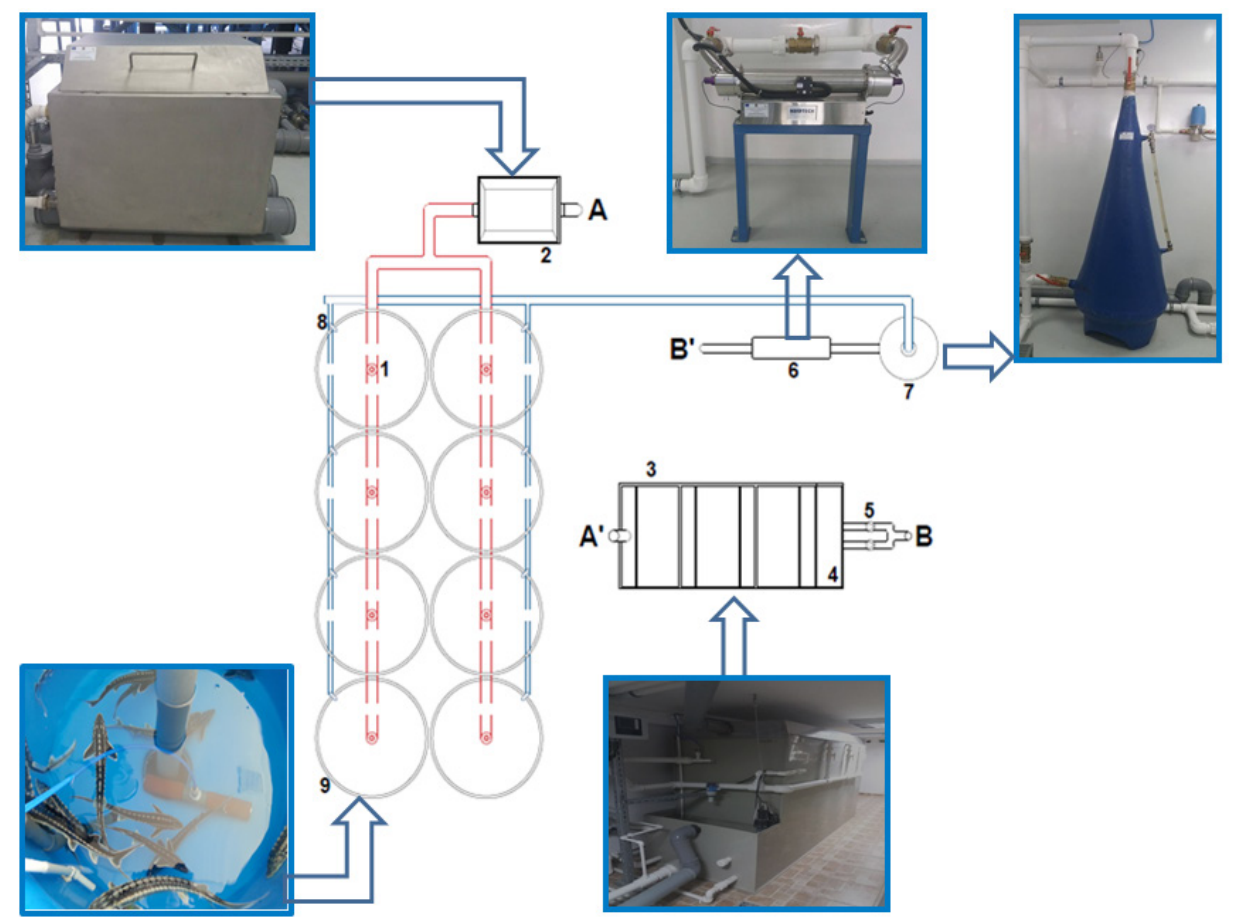

Fig. 1. Schematic representation of the recirculating system

$A-A^{\prime}=$ mechanical filter-biological filter route, $B-B^{\prime}=$ biological filter sump-UV filter route, Rearing unit (water) outlet; 1-Rearing unit (water) outlet, 2-Mechanical filter (Drum filter), 3-Biological filter (MBBR filter), 4-Pump,

5-Pump (and back-up pump), 6-UV filter, 7-Oxygen cone, 8-Rearing unit (water) inlet, 9-Rearing unit

Water quality parameters (temperature, dissolved oxygen and $\mathrm{pH}$ ) were monitored daily with the sensors from the system. Once a week, the nitrogen compounds $\left(\mathrm{N}-\mathrm{NO}_{2}{ }_{2}, \mathrm{~N}-\mathrm{NO}_{3}{ }_{3}, \mathrm{~N}-\mathrm{NH}_{4}{ }^{+}\right)$ were monitored $\left(\mathrm{N}-\mathrm{NO}_{2}, \mathrm{~N}-\mathrm{NO}_{3}, \mathrm{~N}_{-} \mathrm{NH}_{4}^{+}\right)$using Spectroquant Nova400 type spectrophotometer, compatible with Merk kits.

The configuration of the pilot recirculating system was designed and realized to integrate water treatment equipment (mechanical, chemical and biological filters) and rearing units, sized according to a specific technology (Cristea et.al., 2008) (Figure 1).

The integrated components of the recirculating system are grouped into two categories: essential components, including:

eight rearing units, mechanical filter, biological filter, UV lamp for water sterilization and disinfection, pumps, components for the management of dissolved gases (oxygen and carbon dioxide), independent electrical generator; secondary components: monitoring equipment for water quality, food distribution system, raw material storage facilities, facilities for administrative activities.
Each fish was anesthetized $\left(0.3 \mathrm{ml} \mathrm{L}^{-1}\right.$ of 2-phenoxyethanol) and the following biometric characters were evaluated: body weight (BW), total length (TL), standard length (SL), fork length (FL), maximum body depth (last depth of caudal peduncle, $\mathrm{H}$ ); preanal distance (AD), predorsal distance (PD), length of head (C), preorbital distance (PO), length of pectoral fin (LPF), interorbital distance (ID), maximum width of head (MH), width of mouth (WM), width of the head at the level of the mouth (WHM) (Figure 2). Also, we calculate the condition factor for each measured fish: $\mathrm{CF}=\left(\mathrm{BW} / \mathrm{TL}^{3}\right) \times 100$.

Values are presented as means \pm standard errors. Differences statistically significant were calculated in 95\% confidence level. One-way analysis of variance (ANOVA) was applied to compare morphometric characteristics of fish for the four experimental variants. The Duncan post hoc test was used to identify significant differences among the morphometric measurements.

Linear regression relationship and coefficient of correlation were calculated to determine the strength of the relationship between the 

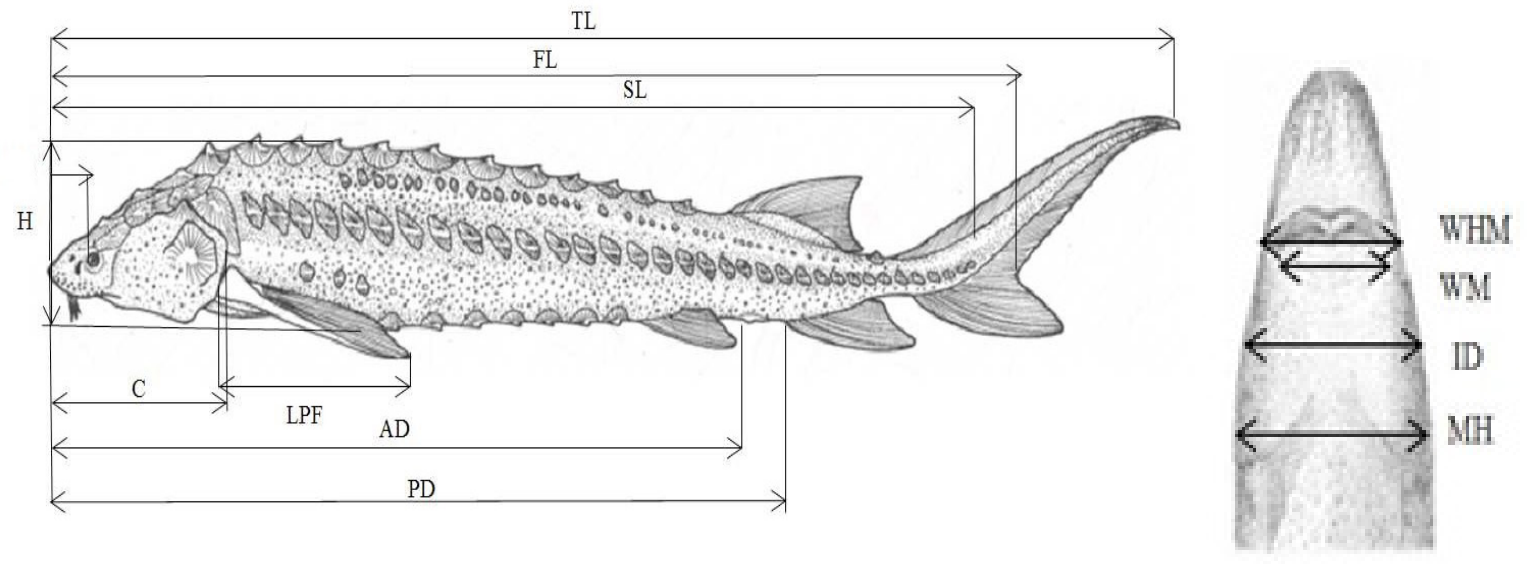

Fig 2. Morphometric measurements made for the fish lots

TL (Total length), FL (Fork length), SL (Standard length), H (Maximum body depth), AD (Preanal distance), PD (Predorsal distance), C (length of head), LS (Preorbital distance), LPF (Length of pectoral fin), ID (Interorbital distance), MH (Maximum width of head), WM (Width of mouth), WHM (width of the head at the level of the mouth)

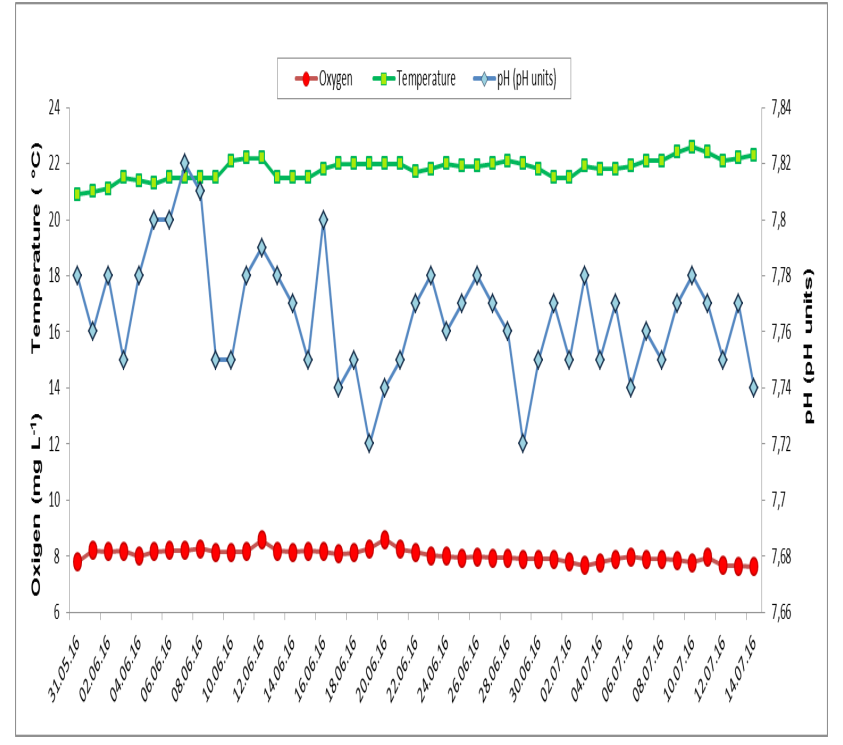

Fig. 3. Water temperature $\left({ }^{\circ} \mathrm{C}\right)$, dissolved oxygen (mg $\mathrm{L}^{-1}$ ) and $\mathrm{pH}$ values during the whole experimental period

morphometric characters. Statistical analysis was conducted using SPSS 21.

\section{RESULTS AND DISSCUTIONS}

During the experiment, the mean values of water temperature, $\mathrm{pH}$ and dissolved oxygen (DO) was $21.82 \pm 1.45^{\circ} \mathrm{C}, 8.03 \pm 0.21 \mathrm{pH}$ units and $7.77 \pm 1.54 \mathrm{mg} \mathrm{L}^{-1}$ respectively (Figure 3 ).

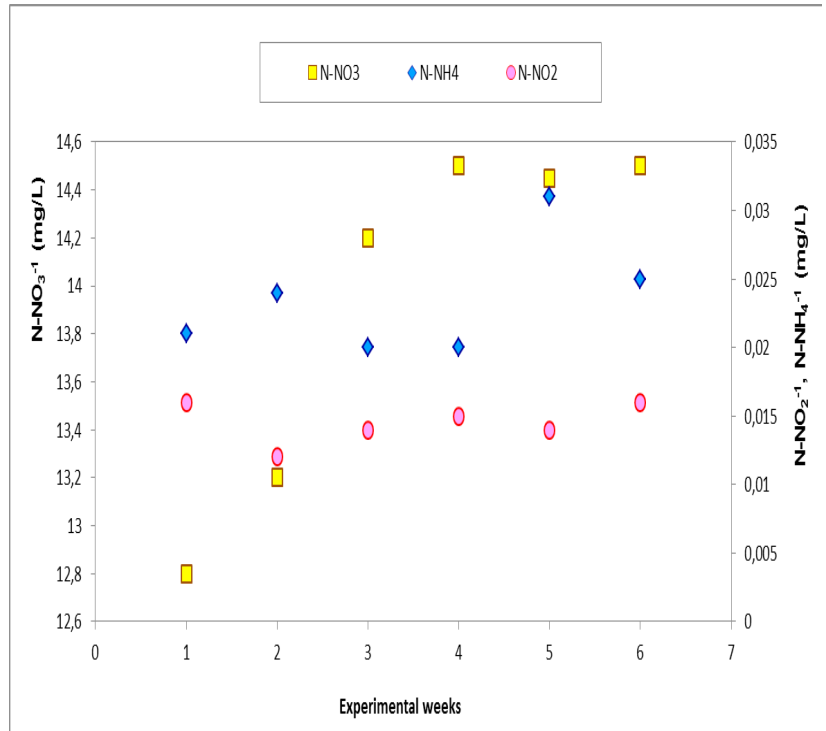

Fig. 4. Nitrate, nitrite and ammonium concentrations during the whole experimental period

Regarding the dynamics of water nitrogen compounds, the average values of nitrate, nitrite and ammonium concentrations were followed: $13.94 \pm 0.74 \mathrm{mgL}^{-1}, 0.015 \pm 0.02 \mathrm{mg} \mathrm{L}^{-1}, 0.024 \pm 0.03$ $\mathrm{mg} \mathrm{L^{-1 }}$. These values were in the normal range recommended for sturgeon growth (Mims et.al., 2002). 
Mean, standard deviation and the minimum/ maximum of all the mophometric measurements are summarized in Table 2.
It is well known the fact that morphometric characters in fishes can show high plasticity in response to a difference in the environmental

Tab. 2. Mean, standard deviation and the standard deviation and the minimum/maximum of all the morphometric measurements at different feeding ratio: $1 \% \mathrm{BW}$ day $^{-1}, 1.5 \% \mathrm{BW}$ day $^{-1}$; $2 \% \mathrm{BW}_{\text {day }}{ }^{-1}$ and the ad libitum $\left(2.8 \% \mathrm{BW}_{\text {day }}{ }^{-1}\right)$

\begin{tabular}{|c|c|c|c|c|}
\hline $\begin{array}{l}\text { Morphometrical } \\
\text { characteristics }\end{array}$ & Exp. variants & $\begin{array}{c}\text { Mean } \\
\pm \text { Std. Deviation }\end{array}$ & Minimum & Maximum \\
\hline \multirow{4}{*}{ BW (g) } & 1\%B.W day ${ }^{-1}$ & $309.50 \pm 50.02 *$ & 245 & 387.00 \\
\hline & $1.5 \%$ B.W day ${ }^{-1}$ & $415.50 \pm 98.42$ & 297 & 540.00 \\
\hline & 2\%B.W day ${ }^{-1}$ & $430.75 \pm 92.36$ & 326 & 583.00 \\
\hline & Ad Libitum & $535.25 \pm 66.51$ & 428 & 580.00 \\
\hline \multirow{4}{*}{ TL (cm) } & 1\%B.W day ${ }^{-1}$ & $46.77 \pm 1.58^{*}$ & 45.40 & 49.70 \\
\hline & 1.5\%B.W. day ${ }^{-1}$ & $48.51 \pm 2.79$ & 44.30 & 53.20 \\
\hline & 2\%B.W day ${ }^{-1}$ & $48.71 \pm .2 .18$ & 46.30 & 52.70 \\
\hline & Ad Libitum & $51.27 \pm 3.22$ & 48 & 56.00 \\
\hline \multirow{4}{*}{$\mathrm{SL}(\mathrm{cm})$} & 1\%B.W. day ${ }^{-1}$ & $35.71 \pm 2.68^{*}$ & 31.20 & 39.70 \\
\hline & 1.5\%B.W. day ${ }^{-1}$ & $37.62 \pm 2.03$ & 34 & 40.00 \\
\hline & 2\%B.W. day ${ }^{-1}$ & $36.80 \pm 1.96$ & 34.50 & 40.50 \\
\hline & Ad Libitum & $39.37 \pm 2.11$ & 36.50 & 42.00 \\
\hline \multirow{4}{*}{$\mathrm{FL}(\mathrm{cm})$} & 1\%B.W. day ${ }^{-1}$ & $39.71 \pm 1.66^{*}$ & 37.70 & 42.60 \\
\hline & 1.5\%B.W. day ${ }^{-1}$ & $41.36 \pm 2.27$ & 37.60 & 44.50 \\
\hline & 2\%B.W. day ${ }^{-1}$ & $41.15 \pm 2.22$ & 38.40 & 45.20 \\
\hline & Ad Libitum & $43.17 \pm 2.84$ & 40.40 & 46.70 \\
\hline \multirow{4}{*}{$\mathrm{H}(\mathrm{cm})$} & 1\%B.W. day ${ }^{-1}$ & $5.15 \pm 0.29 * *$ & 4.70 & 5.50 \\
\hline & 1.5\%B.W. day ${ }^{-1}$ & $5.63 \pm 0.51$ & 5 & 6.40 \\
\hline & 2\%B.W. day ${ }^{-1}$ & $6.03 \pm 0.43$ & 5.50 & 6.80 \\
\hline & Ad Libitum & $5.95 \pm 0.35$ & 5.40 & 6.20 \\
\hline \multirow{4}{*}{$\mathrm{AD}(\mathrm{cm})$} & 1\%B.W. day ${ }^{-1}$ & $26.20 \pm 1.23^{*}$ & 25 & 28.80 \\
\hline & 1.5\%B.W. day ${ }^{-1}$ & $27.13 \pm .1 .65$ & 25.40 & 29.40 \\
\hline & 2\%B.W. day ${ }^{-1}$ & $27.21 \pm 1.44$ & 25.60 & 30.00 \\
\hline & Ad Libitum & $29.07 \pm 1.17$ & 28 & 30.50 \\
\hline \multirow{4}{*}{$\mathrm{PD}(\mathrm{cm})$} & 1\%B.W. day ${ }^{-1}$ & $27.38 \pm 1.17^{*}$ & 26.10 & 30.00 \\
\hline & 1.5\%B.W. day ${ }^{-1}$ & $28.41 \pm 1.87$ & 26.60 & 31.10 \\
\hline & 2\%B.W. day ${ }^{-1}$ & $28.62 \pm 1.84$ & 26 & 31.50 \\
\hline & AdLibitum & $30.55 \pm 1.90$ & 28 & 33.00 \\
\hline \multirow{4}{*}{$\mathrm{C}(\mathrm{cm})$} & 1\%B.W. day ${ }^{-1}$ & $8.23 \pm 0.44^{*}$ & 7.70 & 9.00 \\
\hline & 1.5\%B.W. day ${ }^{-1}$ & $8.58 \pm 0.36$ & 8 & 9.00 \\
\hline & 2\%B.W. day ${ }^{-1}$ & $8.62 \pm 0.48$ & 8 & 9.20 \\
\hline & Ad Libitum & $9.12 \pm 0.23$ & 9 & 9.50 \\
\hline \multirow{4}{*}{$\mathrm{PO}(\mathrm{cm})$} & 1\%B.W. day ${ }^{-1}$ & $3.05 \pm 0.22$ & 280 & 3.50 \\
\hline & 1.5\%B.W. day ${ }^{-1}$ & $3.22 \pm 0.33$ & 2.80 & 3.70 \\
\hline & 2\%B.W. day ${ }^{-1}$ & $3.20 \pm 0.31$ & 2.60 & 3.50 \\
\hline & Ad Libitum & $3.42 \pm 0.43$ & 3 & 4.00 \\
\hline
\end{tabular}




\begin{tabular}{|c|c|c|c|c|}
\hline $\begin{array}{l}\text { Morphometrical } \\
\text { characteristics }\end{array}$ & Exp. variants & $\begin{array}{c}\text { Mean } \\
\pm \text { Std. Deviation }\end{array}$ & Minimum & Maximum \\
\hline \multirow{4}{*}{$\mathrm{LPF}(\mathrm{cm})$} & 1\%B.W. day ${ }^{-1}$ & $5.53 \pm 0.48 * *$ & 4.90 & 6.20 \\
\hline & 1.5\%B.W. day ${ }^{-1}$ & $6.13 \pm 0.67$ & 5.00 & 7.00 \\
\hline & 2\%B.W. day ${ }^{-1}$ & $6.05 \pm 0.55$ & 5.00 & 6.60 \\
\hline & Ad Libitum & $6.42 \pm 0.39$ & 5.80 & 6.70 \\
\hline \multirow{4}{*}{ ID $(\mathrm{cm})$} & 1\%B.W. day ${ }^{-1}$ & $3.28 \pm 0.16^{* *}$ & 3.00 & 3.50 \\
\hline & 1.5\%B.W. day ${ }^{-1}$ & $3.58 \pm 0.21$ & 3.30 & 3.80 \\
\hline & 2\%B.W. day ${ }^{-1}$ & $3.55 \pm 0.30$ & 3.00 & 3.80 \\
\hline & Ad Libitum & $3.72 \pm 0.04$ & 3.70 & 3.80 \\
\hline \multirow{4}{*}{$\mathrm{MH}(\mathrm{cm})$} & 1\%B.W. day ${ }^{-1}$ & $3.97 \pm 0.20 *$ & 3.70 & 4.30 \\
\hline & 1,5\%B.W. day ${ }^{-1}$ & $4.10 \pm 0.38$ & 3.50 & 4.70 \\
\hline & 2\%B.W. day ${ }^{-1}$ & $4.16 \pm 0.25$ & 3.80 & 4.50 \\
\hline & Ad Libitum & $4.47 \pm 0.15$ & 4.30 & 4.70 \\
\hline \multirow{4}{*}{$\mathrm{WM}(\mathrm{cm})$} & 1\%B.W. day ${ }^{-1}$ & $2.46 \pm 0.15^{* *}$ & 2.20 & 2.70 \\
\hline & 1,5\%B.W. day ${ }^{-1}$ & $2.68 \pm 0.25$ & 2.30 & 3.00 \\
\hline & 2\%B.W. day ${ }^{-1}$ & $2.77 \pm 0.22$ & 2.50 & 3.00 \\
\hline & Ad Libitum & $2.67 \pm 0.11$ & 2.50 & 2.80 \\
\hline \multirow{4}{*}{ WHM (cm) } & 1\%B.W. day ${ }^{-1}$ & $3.38 \pm 0.33^{* *}$ & 2.80 & 3.80 \\
\hline & 1,5\%B.W. day ${ }^{-1}$ & $3.77 \pm 0.29$ & 3.40 & 4.20 \\
\hline & 2\%B.W. day ${ }^{-1}$ & $3.88 \pm 0.24$ & 3.40 & 4.20 \\
\hline & Ad Libitum & $3.80 \pm 0.13$ & 3.70 & 4.00 \\
\hline
\end{tabular}

condition, such as food abundance and temperature (Tawwab et al., 2005). Also, the measurable characters are used to describe commercial value, which is determined by various characters to various degrees (Bryliňska, 2000). In the present study, morphometric characters were used to see if different feeding ratio induces some differences among phenotypic characters of Russian sturgeons. Statistically significant differences $(p<0.05)$ were observed in the relative values of most of the measurable characters (Table 2).

The measurable characters changed unequally throughout the four experimental variants. So, the post hoc analysis Duncan shows that the ad libitum variant was a distinct group when we take into consideration the BW, TL, SL, FL, AD, PD, C and $\mathrm{MH}$. The lowest body mass was obtained in the $1 \%$ BW day ${ }^{-1}$ variant, and the highest in the ad libitum feeding, while for the variants $1.5 \% \mathrm{BW}$ day $^{-1}$ and $2 \% \mathrm{BW}_{\text {day }^{-1}}$ the post hoc test revealed almost similar values.

For highlighting more eloquent the differences between the four experimental variants, regression equations were developed for all four tested groups (Table 3).
From the equations presented in Table 3 it can be observed higher correlations between the morphometric characters. The correlation coefficient has been found to be very high in relation to total length. For the 2\% BW day ${ }^{-1}$, the characters like SL, FL, AD, PD, H, shows high value of correlation coefficient in relation

with TL, indicating that these morphometric characters increase in direct proportion to each other's. So, the obtained results indicate that the growth of Russian sturgeon is proportional to the body of the fish. A lower correlation was observed in ad libitum feeding indicating an unequal increase of some morphometric characters (FL, AD).

The condition factor (CF) of a fish reflects physical and biological circumstances and fluctuations by interaction among feeding conditions (Le Cren, 1951). At the end of the experimental period, the mean $\mathrm{CF}$ value ranged from $0.322 \pm 0.04 \%$ for $1 \% \mathrm{BW}_{\text {day }}{ }^{-1}, 0.366 \pm 0.03 \%$ for $1.5 \% \mathrm{BW}$ day $^{-1}, 0.373 \pm 0.04 \%$ for $2 \% \mathrm{BW}$ day 1. Also, in the ad libitum feeding, the higher value of CF $(0.396 \pm 0.037 \%)$, reflect a state of better maintenance of the fish. 
Tab. 3. Regression equations between the morphometric measurements

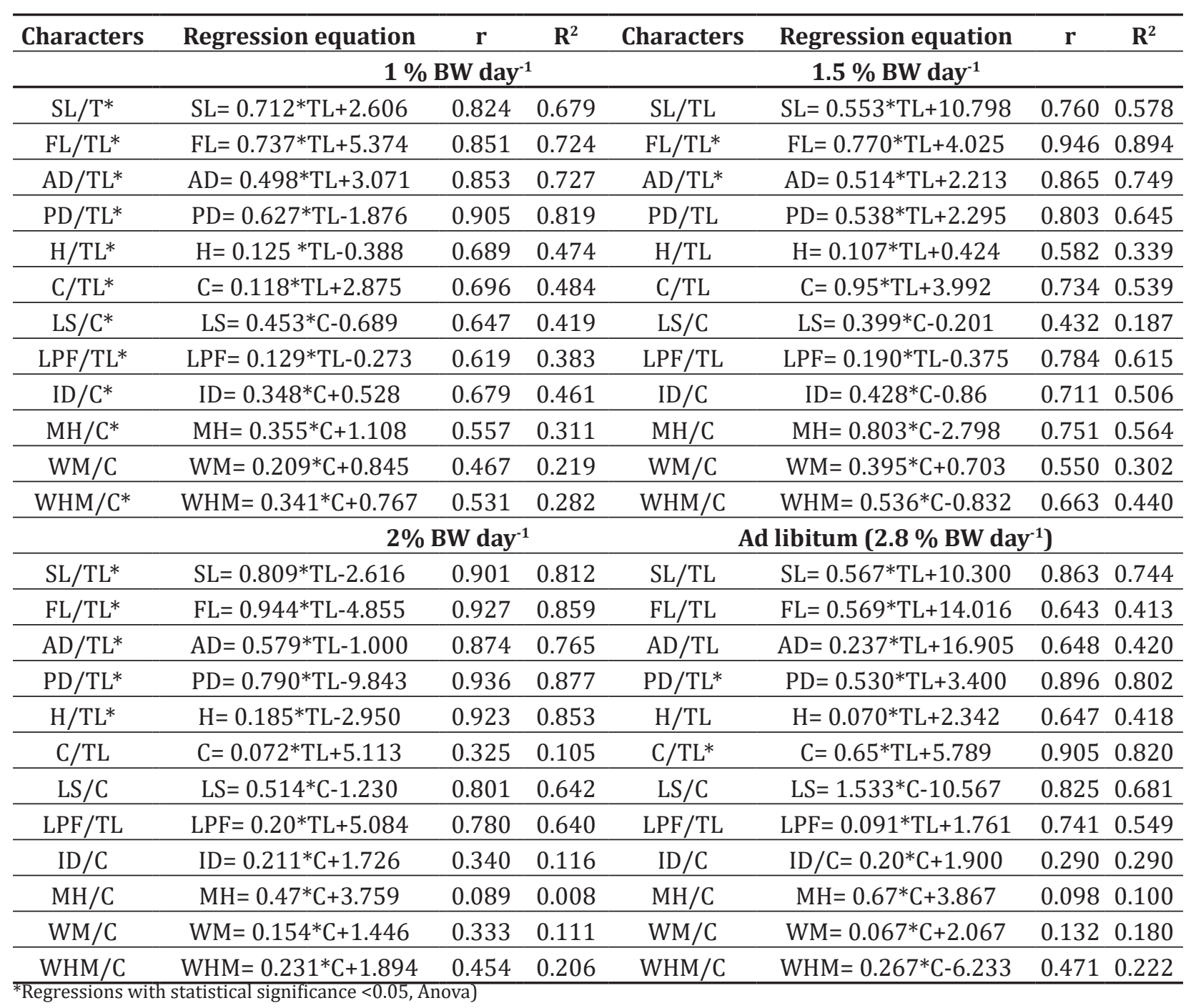

Regarding the most important technological parameter which indicate efficiency of feed for fish (FCR-Feed conversion ratio), the best values were obtained in ad libitum feeding (FCR-1.01), followed by $2 \%$ BW day ${ }^{-1}$ (FCR-1.12 $\mathrm{g}$ feed/g biomass gain), $1.5 \%$ BW day ${ }^{-1}$ (FCR-1.29 g feed $/ \mathrm{g}$ biomass gain) and $1 \%$ BW day ${ }^{-1}$ (FCR-1.69g feed/g biomass gain).

According to some authors (Silva et al., $1995)$ the optimum ration size is that who give the best FCR, while others says that maximum growth occurs at the limit of voluntary food intake (satiation) (Chaco et al.,1990). In our research it was obvious that feeding ratio induced differences between the morphometric characters of the Russian sturgeon. Based on our obtained results, the optimum feeding rate for Russian sturgeon of $250 \mathrm{~g}$ under our experimental conditions seems to be between 2 and $2.8 \%$ BW day ${ }^{-1}$. Since for Russian sturgeon we have not found relevant information in the literature regarding the optimum feeding rate at this size is difficult to compare our findings with other sources or trials. There are some authors (Hung et al., 1989; Hung et al., 1995) who study various feeding percentages and feed efficiency in white sturgeon suggesting that a ratio of $2 \% \mathrm{BW}_{\text {day }^{-1}}$ (at $18^{\circ} \mathrm{C}$ ) is an optimum feeding level for sturgeon size between 250-500 g weight.

\section{CONCLUSIONS}

Generally, in farms feed costs are the greatest costs and, therefore, it is esential to optimize feeding strategy in order to maximize growth and avoiding overfeeding which can be the main source for water quality deterioration (Simensen et al., 2000; Dwyer et al., 2002). 
For Russian sturgeon, there is little information available regarding their feed requirements. In the present research, between the four experimental variants we found clear differentiation in the morphometric measurements. It was observed that all the body parameters show higher values of linear correlation with total length, indicating that the growth of fish in one area of the body is co-related to growth in another area of the body.

This morphological data can be helpful for taxonomists, fisheries and biologists concerned with this fish species, also provides important information in estimating the growth rate for Russian sturgeon, fed with a different ratio. We can conclude that feeding ratio induces major differences between the morphological characters of individuals. Further studies are recommended because there is a lack of information for Russian sturgeon feeding and morphometry.

Acknowledgments: This work was supported by a grant of the Romanian National Authority for Scientific Research and Innovation, CNCS/ CCCDI - UEFISCDI, project number PN-III-P2-2.1PTE-2016-0188, within PNCDI III.

\section{REFERENCES}

1. Bacalbaşa-Dobrovici N (1997). Endangered migratory sturgeons of the lower Danube River and its delta. Environmental Biology of Fishes, 48, 201-207.

2. Barannikova IA, Nikonorov SI, Belousov AN, (2000). Sturgeon conservation in Russia during the present period - In: Proc. Conf. Sturgeons on the Threshold of the XXIst Century, Astrakhan: 7-8 (in Russian).

3. Birstein VJ, Bemis WE, Waldman JR (1997). The threatened status of acipenseriform species: a summary - Environ. Biol. Fish., 48, 427-435.

4. Bryliňska M (2000). Freshwater fish of Poland- PWN, Warszawa, 521.

5. Cacho J, Hatch U, Kinnucan H (1990). Bioeconomic analysis of fish growth: effects of dietray protein and ration size. Aquaculture; 88, 223-238.

6. Cristea V (2008). Scientific partnerships to develop a pilot recirculating system for the promotion and implementation of innovative technologies for superintensive aquaculture. Granted by: Ministry of Education and Research, National Authority for Scientific Research, Program CEEX, Module I, AGRAL. [In Romanian]

7. Dwyer KS, Brown JA, Parrish C, Lall SP (2002). Feeding frequency affects food consumption, feeding pattern and growth of juvenile yellowtail flounder (Limanda ferruginea) Aquaculture., 213, 279-292.

8. Hensel K, Holcik J, (1997). Past and current status of sturgeons in the upper and middle Danube River. Environmental Biology of Fishes, 48, 185-200.
9. Hung SSO, Lutes BP, Storebakken T (1989). Growth and feed efficiency of white sturgeon (Acipenser transmontanus) subyearling at different feeding rates. Aquaculture, 80, 147-153.

10. Hung SSO, Conte FS, Lutes BP (1995). Optimum feeding rate of white sturgeon (Acipenser transmontanus) yearlings under commercial production conditions. Journal of Applied Aquaculture, 5, 45-51.

11. Hossain MAR, Nahiduzzaman M, Saha D, Khanam MUH, Alam MS (2010). Landmark-Based Morphometric and Meristic Variations of the Endangered Carp, Kalibaus Labeo calbasu, from Stocks of Two Isolated Rivers, the Jamuna and Halda, and a Hatchery. Zoological Studies, 49(4), 556-563.

12. King M (2007). Fisheries biology assessment and management. (2nd Ed.), (pp. 1-381). Blackwell Scientific publications, Oxford.

13. Kynard B, Suciu R, Horgan M (2002). Migration and habitats of diadromous Danube River sturgeons in Romania 1998-2000. Journal of Applied Icthyology, 18, 529-535.

14. Yarmohammadi M, Pourkazemi M, Ghasemi A, Saber MH, Chakmehdouz F (2011). AFLP reveals no sex-specific markers in Persian sturgeon (Acipenser persicus) or beluga sturgeon (Huso huso) from the southern Caspian Sea, Iran. Progress in Biological Sciences, No.1, Vol. 1, 5560.

15. Mims SD, Lazur A, Shelton WL, Gomelsky B, Chapman F (2002). Species profile production of sturgeon. Southern Regional Aquaculture Center SRAC, publ. no. 7200, http:// fisheries.tamu.edu/files/2013/09/SRAC-PublicationNo.-7200-Species-Profile-Production-of-Sturgeon1.pdf.

16. Mustafa MG, Brooks AC (2008). Status of fisheries resource and management approach in the open Beels of Bangladesh: a comparative case study. Asian Fish. Sci., 21, 189-203.

17. Rosten CM, Onara D, Hawley K, Suciu R (2012). The status of Danube beluga sturgeon (Huso huso): Past, present and future. Vann, Oslo, 04, 523-534.

18. Silva SS, Anderson TA (1995). Energetics. Fish nutrition in aquaculture. London. Chapman \& Hall, pp.15-25.

19. Simensen LM, Jonassen TM, Imsland AK, Stefansson SO (2000). Photoperiod regulation of growth of juvenile Atlantic halibut (Hippoglossus hippoglossus L.). Aquaculture 191, 119-128.

20. Suciu R (2008). Sturgeons of the NW Black Sea and the Lower Danube River Countries. International Expert Workshop on CITES Non-Detriment Findings, Cancun / Mexico, November 17th-22nd, 27.

21. Tandon KK, Johal MS, Bala S (1993). Morphometry of Cirrhinus reba (Hamilton) from Kanjli wetland, Punjab, India. Res Bull Punjab Univ Sci, 43(1-4), 73-78.

22. Tawwab MA (2005). Predation efficiency of Nile catfish Clarias gariepinus (Burchell, 1822) on fry of Nile tilapia Oreochromis niloticus (Linnaeus, 1758): Effects of prey density, predator size feed supplementation and submerged vegetation. Turkish J Fish Aquatic Sci., 5, 69-74.

23. The IUCN Red List of Threatened Species. http://www. iucnredlist.org/details/232/1, (last accessed: 20 January 2017). 